\title{
"STEALTH LICENSING" - OR ANTITRUST LAW AND TRADE REGULATION SQUEEZING PATENT RIGHTS
}

\author{
Prof. Dr. Nicolas Petit ${ }^{*}$ \\ Liege Competition and Innovation Institute (LCII) \\ University of Liege
}

April 2014

ISBN: 978-3-945185-01-8

* The author is grateful to the TIIC Technology, Innovation and Investment Council e.V. for its support in the drafting of this study. 
"STEALTH LICENSING" - OR ANTITRUST LAW AND TRADE REGULATION SQUEEZING PATENT RIGHTS

\author{
Prof. Nicolas Petit \\ Liege Competition and Innovation Institute (LCII) \\ University of Liege
}

\title{
Introduction
}

A "stealth licensing" paradigm is emerging across the globe. It can be seen through subtle interventions from policy makers, judicial organs and administrative agencies. Those interventions seek to facilitate compulsory licenses outside the TRIPS agreement exceptions and/or to water down those exceptions. ${ }^{1}$ Altogether, they ramp up pressure on patent owners to give away their freedom - it is actually a "right" to exploit their innovations as they see fit. The present paper submits that stealth licensing is a significant phenomenon that adversely impacts the social welfare functions of the patent system. It risks undermining investment in technology, technology creation and the dissemination functions of the patent system at a critical juncture in time, as new critical technologies like green technology, the internet of things, machine to machine technology, smart medical devices or biotechnologies are being called for, and rolled out, across the globe. Moreover, stealth licensing is occurring despite the fact that both private and public investment in R\&D is critical to help developed economies back on the path to growth, competitiveness, employment and prosperity.

This paper explores the concept and policy of "stealth licensing". To that end, it first surveys the literature on the social functions of the patent system, and in particular, on the role of patents to incentivise (risky) R\&D efforts and to disseminate successful technological innovations ${ }^{2}$ (I). In this context, it recalls that whilst divided on the exact function of patent law, scholars broadly concur that patents have social utility. This paper then shows the emergence a "stealth licensing" paradigm adversary to the social functions of the patent system. To aid understanding, it starts with a definition of the concept of "stealth licensing" (II). It then describes its emergence in international trade regulation where a "flexible" interpretation of the TRIPS compulsory licensing exceptions is making way (III); and in antitrust law, where a distinct though equally problematic "undercover" licensing paradigm is gaining prominence (IV). Finally, it explains the perils of squeezing patent rights through stealth licensing with two metaphors: that of a black swan (V) and that of a butterfly $(\mathrm{VI})$.

\footnotetext{
$1 \quad$ Agreement on Trade-Related Aspects of Intellectual Property Rights, April 15, 1994, Marrakesh Agreement Establishing the World Trade Organization, Annex 1C, 1869 U.N.T.S. 299, 33 I.L.M. 1197 (1994) (hereinafter "TRIPS"), Article 31.

2 The term "innovation" is used, in this paper, to mean the industrial exploitation of a patented invention, following research and development efforts.
} 


\section{Goals of the Patent System}

\section{Survey of the economic literature}

The literature assigns several functions to the patent system. The first is to incentivize innovation or, more accurately, innovation investments (eg, R\&D expenditures). The theory goes as follows: inventive knowledge is costly to produce; yet, given its intangible nature, it is comparatively cheap and risk-free to imitate. Absent economically affordable means to appropriate their investments (eg, through the secret protection of their innovation), inventors renounce to innovation investments ex ante (Arrow, 1962) anticipating that ex post they will face the competition of free riding imitators who enjoy a drastic cost advantage, as they do not need to recoup the sunk costs of R\&D expenditures (Posner and Landes, 2003). There is underinvestment in socially desirable activities.

Patent protection is the governmental attempt to address this problem. With a patent, innovators can fence off ex post free-riders. And welfare enhancing investments are not deterred ex ante. This theory has received many labels: Schumpeterian innovation, "incentive model', "reward theory", etc. Whatever the label, the underlying argument is the need for innovators to recover the costs necessary to bring an invention to the market (Scherer, 1980), as well as the costs of failed R\&D attempts and the cost of risk capital. This theory, though intuitively appealing, remains theoretically and empirically disputed (Lemley, 2011).

The second function ascribed to patent protection is to enable technology dissemination. As aptly put by Gallini and Winter, by "protecting property rights, patents here open the market for trade in technological information" (Gallini and Winter, 1985). In brief, patents make contracts possible between inventors and third parties (producers but also innovators). ${ }^{3} \mathrm{~A}$ patent, which is the legal emanation of a specific technology, provides a legal construct that creates a necessary level of legal certainty to incentivise patent owners to share their inventions and know-how. Absent patents, technology transfer would be fundamentally undermined. No innovator would disclose an inventive idea or its functioning to third parties, for once disclosed, he has nothing left to sell (Käseberg, 2012). And no purchaser would ever buy an invention that he can imitate freely. The patent system solves this basic "disclosure paradox" issue (Arrow, 1962). It incentivizes innovators to trade - and before it to disclose - information to the benefit of society. This "makes a contribution to innovation which is pluralistic and increasingly collaborative" (Anderman, 2012). Indeed, the patent system provides the incentive to transfer the

3 This is the less well-known, though equally as important, "Coasian" function of the patent system (after the name of Nobel Prize economist Ronald Coase, the father of transaction costs theory). 
knowledge and know-how often required to correctly implement, maintain and upgrade complex patented technology.

A third, and related, justification for patents has been highlighted by Kitch in a seminal paper (Kitch, 1977). Patents are like "prospects" in mineral exploration: they signal research avenues to other innovators, like prospects signal territories of interest to mine developers. In particular, patent owners can channel research directions and "coordinate the search for technological and market enhancement". Moreover, patents reduce "the amount of duplicative efforts in innovation" and save "resources devoted to keeping the technology secref", including non-patentable information gathered at development stage. Put differently, patents act as "development rights" (Cheung, 1982 and 1986). They are useful to society besides the incentives to innovate of, and the rewards granted to, inventors.

A fourth function of patents is to send signals to observers, and in particular to investors on capital markets (Long, 2002). This is because "analysts often treat patents as a benchmark of a firm innovativeness", or "to benchmark firms relative to others", etc. Patents help overcome information asymmetries, by entitling observers to more accurately and less costly measure the quality of a firm (and its research projects). Small firms seeking to leverage venture capital can for instance overcome investors' reluctance if they hold a strong patent portfolio and studies have shown that small firms that possess patents protecting their technologies will attract more venture capital and indeed grow faster than firms that do not (Holgersson, 2013). Properly managed patent portfolios together with a wellconstructed IPR strategy can serve as cost-effective and credible signals, which reduce investors' risk.

Fifthly, the New Institutional Economics school argues that patent ownership rules reduce the "transactions costs" incurred with other forms of knowledge protection such as trade secrecy and contract law (Heald, 2005). The reasoning is simple: to appropriate an idea, an inventor must shield it from a whole range of agents, including creditors, heirs of investors, subcontractors, employees, etc. To that end, it must conclude with them a myriad of costly confidentiality and non-compete agreements. Patents are less costly than the transactions costs of designing, drafting, negotiating and concluding such contracts.

Similarly, patents decrease transaction costs at the enforcement stage, by providing inventors with supportive institutions in case of dispute (Merges, 2005). All in all, new institutional economics theories are linked with the second function of patents. They show that patents "enable trading in information assets, stimulating a thicker market in technological information" (Heald, 2005). 


\section{Discussion}

Our survey of the literature brings the following thoughts. Firstly, the copious empirical literature on patents does not decisively point to one primary goal of the patent system and leading scholars concede that their theory remains an "incomplete justification" for the entire patent system (Kitch, 1977). In the same vein, many economists recognize that the patent system is a welfare enhancing, multi-purpose instrument serving a variety of goals, even though disagree they on the relative importance of those respective goals. In our view, the inability of scholars to reach a unifying agreement on a given function for the patent system is not a cause of concern. Similar divides exist in other branches of the law. In antitrust law, for instance, scholars have been fretting for decades over the goals of competition rules (consumer welfare $\mathrm{v}$ producer welfare; protection of consumer choice, safeguarding of small businesses; industrial policy; etc.)?4

Secondly, both the incentivization to develop technology and the dissemination functions dominate the scholarship. Interestingly, the literature on technology dissemination describes the patent system as a sine qua non condition for technology dissemination. This is because patent protection commoditizes innovation (Troy and Werle, 2008 talk of a "fictitious commodity"). It transforms an idea into an asset that can be bought and sold on a commercial market (Mc Donough, 2006). Absent the patent system, there would be no technology dissemination other than marginal, benevolent distribution. Importantly, the literature suggests that the design of the patent system is critical to the efficiency of the patent market. For instance, some empirical studies show that the stronger the patent protection, the higher the probability of licensing (Gambardella et al., 2007). ${ }^{5}$

Thirdly, most studies in our sample focus on the firm, the patent system and innovation. But many studies also explore the role of government - or of other agents - in promoting innovation through other mechanisms, such as educational policy, labor policy, tax policy (eg, subsidies, rewards or fiscal incentives), etc. Those studies stress that patent protection is not the sole means to promote innovation, and that many government-related mechanisms play a key role in the generation of ideas, information and inventions. That said, one should not forget that if government policy clearly supports innovation, it is investors and companies that remain those that take the risks in testing new technologies, implementing them, and bringing them to the market. Moreover, publicly-funded R\&D

$4 \quad$ Interestingly, the patent academics reflect on the function of the patent system, but this rarely results in policy change. Unlike in antitrust law, where the discussion over the functions of the legal system often give rise to critical changes in practices, as the antitrust thinkers are usually the agencies that enact their conclusions.

5 Similarly, the higher the uncertainty, the lesser the liquidity of patents (Troy and Werle, 2008). 
investments need patent protection too. And lastly, patent protection is, in itself, a form of public policy. Its purpose is to encourage, incentivise, nudge investors to publicise R\&D results so as to foster social benefit and welfare.

\section{Definition of Stealth Licensing}

This paper's submission is that the various social functions of the patent system are endangered by the rise of "stealth licensing". This novel concept means a progressive and subtle enlargement of the two exceptions of compulsory licensing provided respectively under Article $31 \mathrm{~b}$ ) and k) of the TRIPS agreement, namely the "national emergency or other circumstances of extreme urgency or in cases of public non-commercial use" exception (hereafter, exception 1) and the "anticompetitive practices" exception (hereafter, exception 2). ${ }^{6}$

This enlargement takes place at two levels, which jointly dilute patent rights. First, some propose to make compulsory licensing more "flexible" in international law - and by the same token in national law in response to global macro-economic imbalances. This may lead, for instance, to relax the strict exception 1 of the TRIPS agreement. Second, in antitrust law, legal interpretations which facilitate antitrust intervention on patent holders' market conduct are flourishing. This gives rise to an "undercover" expansion of exception 2 of the TRIPS agreement.

In our opinion, those top down - changes in IP regulatory frameworks at the international and national levels - and bottom up - intervention in the market place, to change patent holder conduct interventions are not devoid of effects on patent owners. Much like compulsory licensing, they risk squeezing the patent rights, by placing them between hammer and anvil. Since these exceptions have differences, the following chapters discuss separately the rise of "flexible" compulsory licensing in international trade regulation (III) and of "undercover" licensing in antitrust law (IV).

With this background, some lexical clarifications are in order. We deliberately use the adjective "stealth" licensing, because instrumentally those measures do not mandate outright compulsory licenses reviewable by courts (what one could refer to as "hard licensing"). Rather, they ease the formulation of such orders, by lowering the threshold for intervention under the TRIPS exceptions. This phenomenon can be observed in the international trade arena, where pressure is not exerted on patent owners directly, but through calls for a relaxation of the regulatory framework. It can be observed in antitrust law too. There, what is in question are incremental changes in legal tests, standards, interpretations and doctrines, which bring patent owners one step closer to antitrust licensing orders. For instance, the

$6 \quad$ See Article 31 b) and k) respectively. 
blanket and novel suggestion from the European Commission that companies that have developed successful platforms should be "encouraged" to license interoperability information, with no reference to market power, barriers to entry, or to the established theories of antitrust intervention is a clear symptom of stealth licensing?.

But we also use the expression "stealth" licensing, because formally, many of those measures are not embedded (yet?) into clearly binding and judicially reviewable "hard law" instruments, and so exist in a variety of soft law instruments such as declarations, speeches, reports, etc. Much like "hard law" compulsory licensing, however, such measures may disincentivise patent holders' from creating and disseminating technology and one can argue that they are expressly intended to change the behaviour of patent owners. The ability of regulators to obtain remedies without formally enforcing the law is, after all, well documented in the legal and economic literature. For instance, papers on "sunshine regulation" recall that at the end of the XIXth century, in the US, the railway regulator devised a method of intervention based on naming and shaming (Petit and Rato, 2009). This literature shows that regulators may rely on informal pronouncements (press releases) and soft law instruments to discipline market players without the need (or risk) of adopting a formal decision.

Our concept of stealth licensing could be criticized as overly broad. Many other policies that also weaken patents, incentives to innovate and technology dissemination could fall within our proposed definition. Take education policy. Cuts in university budgets or rise of tuition fees elevate barriers to education, and in turn may limit the production of innovative idea in society. But this does not amount to stealth licensing, for such measures do not really seek to regulate patent rights and, through that, technology ownership.

\section{III. "Flexible" Licensing in International Trade Regulation}

\section{Inception of "Flexible" Compulsory Licensing: The Pharmaceutical Sector}

Stealth licensing is primarily observable in international trade regulation, where a "flexible" compulsory licensing doctrine ("FCL") is making way. In recent years, demands to the effect of relaxing the restrictive compulsory licensing derogations set forth in article 31 of the TRIPS agreement have escalated, in particular in relation to the derogation which entitles countries to order licenses in

7 See the EU Digital Agenda Action 25 at http://ec.europa.eu/digital-agenda/en/pillar-ii-interoperabilitystandards/action-25-identify-and-assess-means-requesting-significant and the European Commission's Staff Working Document http://ec.europa.eu/digital-agenda/en/news/analysis-measures-could-lead-significant-market-players-ict-sectorlicense-interoperability. 
instances of "national emergencies or other circumstances of extreme urgency or for public noncommercial purposes". ${ }^{8}$

Originally, those demands emanate from developing countries, seeking to secure cheap access to pharmaceutical products. In the end 1990s, those countries voiced increasing concern over the prohibitive cost of key patented drugs (and/or licenses) sold by Western firms.

In response to such demands, WTO members embraced in 2001 a doctrine of "flexibility". In the Doha declaration, they affirmed that given 'the gravity of the public health problems afflicting many developing and least-developed countries", there should be "a right of WTO members to use, to the full, the provisions in the TRIPS Agreement, which provide flexibility for this purpose". 9 This shift in legal policy entitled developing countries to issue compulsory licenses. The FCL doctrine was turned into practice in Africa, Asia and India, where compulsory licenses were issued over anti-retroviral drugs useful for the treatment of HIVIAIDS.

\section{Extension of "Flexible" Compulsory Licensing?: Green Technologies}

In recent years, developing countries have sought to expand the FCL doctrine to "green technologies". Green technologies (also known as "clean technologies", "environmentally sound technologies", or "climate change mitigating technologies") are technical solutions that protect the environment without reducing economic activity: renewable energy, ${ }^{10}$ clean fossil fuels, carbon capture and storage technologies, measures which reduce carbon emission, ${ }^{11}$ etc. Like in pharmaceuticals, the argument goes that patents impede to the diffusion of green technology in developing countries (Sovacool, 2008). This in turn would yield dramatic consequences, for developing countries lack sufficient resources to finance green-technology research, yet pollute more than others (Fair, 2009). ${ }^{12}$

Ahead of the 2009 Copenhagen Summit on Climate Change, the developing countries parties to the United Nations Framework Convention on Climate Change ("UNFCCC") put forward proposals to weaken (or even eliminate) IPRs in green technologies. China and India proposed to mandate compulsory licensing of patented technologies or to introduce explicit derogations for green

\footnotetext{
$8 \quad$ See Article 31b) TRIPS.

9 Declaration on the TRIPS Agreement and Public Health, WT/MIN(01)/Dec/2, 14 November 2001, available at http://www.wto.org, (hereinafter "Doha Declaration"], paragraph 4 to 6.

10 Eg, wind, biomass, photovoltaic, tidal/wave, geothermal

$11 \quad \mathrm{Eg}, \mathrm{CO} 2$ free and low-carbon technology.

12 Some also argue that compulsory licensing to developing countries like China and India would be efficient for the western world, given the huge comparative cost advantage of the former, where cheaper manufacturing capabilities are available, notably in wind and solar energy (Gupta, 2012).
} 
technologies in the text of the TRIPS agreement (Maskus, 2010). Bolivia, the Philippines and Indonesia proposed to exclude patents for environmentally sound technologies. ${ }^{13}$

Several high level politicians backed those proposals. Bolivian President Evo Morales ran riot against IPR in climate change technology requesting that "all countries can access products already patented [...] free of cost'. ${ }^{14}$ Similarly, a number well established Western international institutions such as the World Bank or the European Parliament joined the cause. ${ }^{15}$

To date, those arguments have not garnered legal traction. The Copenhagen Conference and the 2012 Doha Climate talks resulted in no declaration or agreement on IPR and green technologies. But the issue remains live. At the Warsaw Climate Change conference in November 2013, the ministers stressed "the urgent need to address the issue of [...] the appropriate treatment of intellectual property rights, including the removal of patents on climate-related technologies for non-Annex I Parties". ${ }^{16}$ And in India, the "National Manufacturing Policy" plan has proposed to set up a Technology Acquisition and Development Fund which will be able to petition the Government for compulsory licenses in relation to "Green Technologies" (if the technology is not offered by the patent holder at reasonable rates or it is not being provided in India to satisfy the domestic demand). ${ }^{17}$

13 See FCCC/AWGLCA/2009/8 19 May 2009, Ad Hoc Working Group on Long-Term Cooperative Action under the Convention, Sixth session, Bonn, 1-12 June 2009

14 See http://www.ip-watch.org/2009/04/01/cooling-the-world-by-misappropriating-patent-rights/ See also, Xie Zhenhua, President Hu Jintao's Special Representative on Climate Change and Vice Chairman of the National Development and Reform Commission of China: "Developed countries should also fulfill their obligations under the Convention to provide financial support and technology transfer to enable developing countries to effectively tackle climate change."; Shyam Saran, climate change envoy to Indian Prime Minister Manmohan Singh, India, saying that technology transfer to developing countries is "a burning issue" and that "intellectual property rights may need to be slacked for it." In the same vein, India wants "a global fund that could buy out IPRs of green technologies, and then distribute these technologies free, in a way that is similar to what is done for HIVIAIDS drugs."; And Minister Shri Ramesh, Indian Climate Change, who declared that access to intellectual property for low-carbon technology is a "global public good": http://online.wsj.com/news/articles/SB124760260278140953

15 See World Bank (2012) "Inclusive green growth, the pathway to sustainable development" stating: "Making it easier for countries to issue compulsory licenses under appropriate circumstances can help ensure more affordable access to patented green innovations by poorer households in low-income countries"; See European Parliament, Resolution of 29 November 2007 on trade and climate change (2007/2003(INI)) Green position paper (2012) Climate change, Technology Transfer and Intellectual Property: http://www.greens-efa.eu/climate-change-technology-transfer-and-intellectual-property5484.html which states that: "Equally important ...is the right of developing countries to use the full TRIPS flexibilities, including compulsory licensing".

16 See http://www.twnside.org.sg/title2/climate/info.service/2013/climate131011.htm

17 See http://www.thehindubusinessline.com/industry-and-economy/us-eu-irked-by-indias-compulsory-licence-planfor-green-technologies/article5193594.ece and http://www.financialexpress.com/news/us-uk-question-nmp-s-green-techprotection/1177391/1. The US Chamber of Commerce indicates serious impact on jobs, in case compulsory licensing will be applied for "Green Technologies". See http://dev.theglobalipcenter.com/wp-content/uploads/GIPC__Green_Jobs_Leave_Behind.pdf 


\section{Discussion}

The "flexible" compulsory licensing doctrine has a number of specific features which deserve to be discussed.

a. The "Patent=BarRieR" Equation. The rhetoric of FCL often relies on questionable lexical shortcuts. For instance, IPR are often equated with a "barrier" to trade. In the recent UNFCCC, the Like-Minded Developing Countries (ie 133 developing countries anchored in G77+China) noted that "Annex I countries should put in place the enabling environment in their own countries that will remove the barriers (such as cost and IPRs) to technology development and transfer and enable them to effectively implement their technology development and transfer obligations to developing countries". 18 Both China and India's submissions on the same topic categorize IPRs as "barriers". ${ }^{19}$

b. The "Moral" Justification of FCL. The pro-FCL movement also justifies extensions of the doctrine on grounds of higher societal, human or moral purposes. In this respect, FCL in green technology is often presented as a corollary of fundamental rights, as it was in the pharmaceutical sector with respect to the right to health, etc. On close examination however, the analogy with the pharmaceutical sector appears unjustified. No specific human rights legal basis is advanced in support of the application of the FCL to green technology, and one may question whether such a legal basis actually exists. Moreover, the sole possible legal basis that springs to mind is the right to a sustainable environment. However, to date, this right has only been recognized - and with many caveats - in some developed countries, and has never been in developing countries.

c. The Politicization of FCL. The "flexible" compulsory licensing model advances in high level political forums. In such circles, there is no place for thorough empirical, "evidenced-based" discussion. Rather, debates are (i) dominated by intuitive, qualitative and self-supporting arguments (unlike maybe, in antitrust law which follows a more robust, though necessarily imperfect, approach through adjudication);20 and (ii) affected by negotiation and bargaining dynamics, intrinsic to any politicized process.

The debate surrounding green technologies perfectly illustrates this. First, the analogy drawn by policy makers between pharmaceutical and green technologies has little, if no empirical footing. In the pharmaceutical industry, many base technologies (ie drugs) must still be discovered; and when they are

\footnotetext{
$18 \mathrm{http}: / /$ unfccc.int/bodies/awg/items/6656.php\#workstreamone

19 http://unfccc.int/bodies/awg/items/6656.php\#workstreamone

20 Though the alleged superiority of antitrust is less true when it advances through general policy statements/discussions.
} 
discovered, they cannot be substituted (Henry, 2010). This means that market players compete over "drastic" innovation. And drastic innovation is both very costly and risky. In contrast, in green technology, most base technologies derive from prior periods of R\&D, for instance in the 1970s. ${ }^{21}$ Those technologies are no longer protected by patents..$^{22}$ Innovation is thus essentially "incremental". It takes place over specific improvements or features. ${ }^{23}$

This is important because this means that developing countries can avail themselves of a significant stack of unpatented drastic green technology (Copenhagen Economics, 2009). Of course, developing countries may also need to practice incremental technologies. But those technologies are less costly to develop than drastic innovation. Moreover, there are more substitutes on incremental technologies than on drastic ones (Fair, 2009).

Second, the claim that the price of green technology would be anticompetitive is too contradicted by empirical analysis. Professor Barton has scrutinized the market structure in several green technology sectors, as a proxy for price competition in those industries. He finds that in the photovoltaic sector, the developing nations face a loose oligopoly structure, with many entrants. China, for instance, has developed and produced, successful solar panel technology. Similarly, developing nations have good access to the current generation of biofuel technology. Finally, the wind sector is competitive and developing nations can build wind farms with equipment from the global market without enormous $\mathbb{I P}$ costs.

In the same spirit, other studies empirically confirm that technology transfer in green technology happens between developed and developing countries. A WIPO meta-analysis of the empirical literature reports that in "the existing evidence-based studies, most seem to suggest that IP rights are not a barrier to the transfer of ESTS and that, together with a range of other factors, they may play a positive role in facilitating the transfer of ESTs" (Perez Pugatch, 2011). At a higher level of granularity,

21 See E.L. Lana, "Clean Tech Intellectual Property: Eco-marks, Green Patents, and Green Innovation", Oxford, Oxford University Press, 2011, 6 (hereinafter "Clean tech for IP is for real"): "Solar technology went through a period of innovation in the 1970s following the oil crisis of that era. The idea of using ocean waves to generate electricity has been around for a long time; the first patent application for an ocean power device was filed in the eighteenth century. Wind energy, too, is not new. Wind has been harnessed as a source of power for hundreds of years, and the modern wind power industry was born in the 1980s".

22 See "Clean tech for IP is for real", 9 and 10.

$23 \quad$ Barton notes that "the basic approaches to solving the specific technological problems have long been off-patent. What are usually patented are specific improvements or features", see J. H. Barton, (2007) "Intellectual Property and Access to Clean Energy Technologies in Developing Countries: An Analysis of Solar Photovoltaic, Biofuels and Wind Technologies", ICTSD Trade and Sustainable Energy Series Issue Paper No. 2, International Centre for Trade and Sustainable Development, Geneva, Switzerland. 5. 
Lane brings evidence of nine significant clean technology transfers towards developing countries in the year preceding the Copenhagen climate change conference.

In sum, patents are not a proven barrier to the dissemination of green technology. In the literature, other elements are described as possible impediments to the uptake of green technology in developing countries: insufficient technical knowledge to produce innovative technologies locally, insufficient market size to justify local production units, unfavorable market conditions and investment climate, ineffective government and institutions, etc. (UNEP, EPO and ICTSD study, 2010).

All in all, it is doubtful that the new licensing flexibility introduced in the pharmaceutical sector - which in itself, is disputable on its own merits - can or should be replicated in the green technology sector. Moreover, some authors rightly stress the adverse signals of $F C L$ in green technology: compulsory licensing for a particular technology may decrease the incentive for other multinational companies to engage in joint ventures with local firms in that state (Fair, 2009).

\section{IV. “Undercover" Licensing in Antitrust Law}

\section{Compulsory Licensing in Antitrust Law}

"Hard" compulsory licensing on the basis of competition rules remains epiphenomenal. In about 50 years of EU competition enforcement, there have only been 4 cases of compulsory licensing of IPRs in the EU ("European Union") legal system, ie DSD, Magill, IMS Health and Microsoft. And all those cases concerned respectively trademarks, copyright, database protection, software interfaces, IPRs that are less rigorous that patents.

This finding holds true at the global level. A 2011 WIPO survey on compulsory licenses reports that whilst antitrust-based compulsory licensing is theoretically available in most jurisdictions, it is "seldom applicable in practice". ${ }^{24}$ Concerns of "hard" competition-based compulsory licensing in the academic literature are thus off the wall. ${ }^{25}$

Several indications however suggest the rise of a more insidious "stealth" licensing paradigm in antitrust law. It takes shape through a collection of legal precedents and policy pronouncements which taken altogether impose on patent holders the prospect of being under an antitrust duty to license their

\footnotetext{
24 See WIPO, CDIP/4/4 Rev./STU*DY/INF/5, p.24.

25 See for an example of such concerns, F. Fine, "European Community Compulsory Licensing Policy: Heresy Versus Common Sense", 24 NW. J. INT'L L. \& BUS. 619, 619 (2004), arguing that what dilutes intellectual property rights is not the possibility of compulsory licensing, but the frequency by which the EC and the ECJ mandate a compulsory license. See also, Katarzyna A. Czapracka, "Where Antitrust Ends and IP Begins - on the Roots of the Transatlantic Clashes", 9 YALE J.L. \& TECH. 44, 47-48, 72-77 (2007). However, we do not talk here of compulsory licensing in the context of merger proceedings, because such measures are submitted and approved by the parties.
} 
technology. The following paragraphs describe those symptoms in turn, though not all are of equal importance.

\section{The Evidence}

a. The "Patent=Monopoly" Equation. The first symptom of stealth licensing is the inveterate tendency of competition agencies, judges and scholars to equate a patent with a monopoly. In turn, just by virtue of their IPR, patent holders would be allegedly dominant, and enjoy significant market power. ${ }^{26}$ The Court of Justice of the European Union ("CJEU") itself has set the mark, affirming that: "a medicine is protected by a patent which confers a temporary monopoly on its holder". ${ }^{27}$ Likewise, antitrust agencies have voiced concern about "the surge in the strategic use of patents that confer market power to their holders" ${ }^{28}$ And a vast majority of respondents to a 2011 WIPO study consider that IP rights "confer market power per se" or a "legal monopoly". Lastly, influential academics have claimed that "the patent system is designed to create market power". ${ }^{29}$

The patent=monopoly theorem is a clear symptom of stealth licensing. Pegging patent to monopolies eases the application of the competition rules on "abuse of dominance" (in the EU, Article 102 TFEU and in the US, Section II of the Sherman Act). To be sure, in most competition regimes, "dominance" is not alone a cause of remedial intervention. However, in Europe, a finding of dominance constitutes the first of the two components of an infringement of Article 102 TFEU. With the patent=monopoly proxy, agencies and courts thus lift $50 \%$ of the burden of proof of an infringement, having solely to prove "abuse" to apply Article 102 TFEU.

b. The "IP ATHeISm" Doctrine. The world of competition agencies is flat: whilst most antitrust agencies profess market-specific approaches, they meanwhile consider that IPRs intensive sectors have nothing specific. In short, IPRs are just an asset like any other. And like tangible assets, they may be subject to heavy-handed remedial intervention. The EU Commission said just this in Microsoft: "intellectual property rights are not in a different category to property rights as such" ${ }^{30}$

26 See S. Bostyn and N. Petit, "Patent=Monopoly: A Legal Fiction", SSRN: http://ssrn.com/abstract=2373471 or http://dx.doi.org/10.2139/ssrn.2373471 pp 19.

27 See CJEU, C-468/06 to C-478/06, Sot. Lélos kai Sia EE and Others v GlaxoSmithKline AEVE, [2008] ECR I-7139, $\S 64$.

28 See J. Almunia, Speech at Industrial policy and Competition policy: Quo vadis Europa?, New Frontiers of Antitrust 2012 - Revue Concurrences Paris, 10 February 2012.

29 See Professor Tim Wu, Columbia University, Oversight of Innovation Catalysts, 2012 OECD Competition Committee Hearings on the Digital Economy.

30 See Commission Decision, Microsoft, Case No COMP/C-3/37.792 [2004] OJ C (2004) 900 final, §550. 
In other cases, antitrust agencies explicitly skirt the issue. For instance, in Thomson Reuters, the EU Commission rebuffed the parties' argument to the effect that the impugned conduct involved IPRs by stating that: "the Commission does not take a view on whether RICs [Reuters Instruments Codes codes used by Thomson Reuters to identify financial instruments and indices] are protected by intellectual property rights". ${ }^{31}$

Finally, antitrust agencies occasionally downplay the existence of IPRs by passing judgment on their invalidity. In Standard and Poor's for instance, the EU Commission held that "the mere use of numbers for reference purpose is not capable of being subject to copyright'. ${ }^{32}$

c. AntI IP PRIORITY-Setting? Antitrust agencies are resource-constrained. They must set enforcement priorities. Interestingly, in the past decade, antitrust agencies have placed a clear focus on patent intensive sectors. In the EU, for instance, Commissioner Kroes allocated vast resources to a wide ranging inquiry in the pharmaceutical sector, upon suspicion of abuses of the patent system, making light of the highly restrictive exceptions imposed by the European courts. And her successor, Commissioner Almunia, devoted large enforcement resources to high technology cases where patents (and copyrights) are numerous. In 2014, the European Commission was investigating at least 9 such cases, Apple vs Motorola; Microsoft vs Motorola; Huawei vs InterDigital; Google vs Microsoft/Nokia/Mosaid; Apple vs Samsung; Sierra Wireless vs Nokia; MathWorks; Icera v Qualcomm; Honeywell/Dupont JV. And a high level official, C. Madero, indicated that there were several other cases in the decisional pipeline. ${ }^{33}$

This, of course, does not suggest an anti-patent bias. Not all patent intensive sectors are subject to intense antitrust scrutiny. Sectors such as industrial machinery, the automotive industry or biotechnologies have for instance been subject to light antitrust scrutiny. Yet, the selection of two highly visible patent intensive sectors as enforcement priorities may nurture the perception that antitrust enforcers are anti-patent. And there is no doubt that the evolution of antitrust law, in Europe and further afield, will draw on these precedents.

d. Antitrust Determinations of Weak Patents. Patent validity assessments are outside antitrust agencies' jurisdiction. Those matters belong to patent offices and the judiciary. Despite this, however, antitrust agencies occasionally challenge the validity of patents, and use findings of invalidity as a basis

31 See Commission Decision, Reuters Instrument Codes (RICs), Case No COMP/39.654 [2012] C (2012) 9635 final, $\S 90$.

32 See Commission Decision, Standard \& Poor's, Case No COMP/39.592 [2011] C (2011) 8209 final, §41.

33 See M-Lex, EC to reveal position in tech-patents cases in 'near future,' Madero says, 7 December 12, Matthew Newman. 
for antitrust liability. The burgeoning case-law on pay-for-delay settlements in the pharmaceutical sector shows this. In the ordinary pay for delay case, a pharmaceutical patent holder ("originators") makes a reverse payment to a generic entrant in order to end patent invalidity proceedings. With this financial transfer, the originator fences off his generic rival from the market, and can continue to exploit its patent until expiry.

With this background, in Servier, the EU Commission held that such reverse payments constitute restrictions of competition "by object" (ie egregious and de facto) pursuant to Article 101 TFEU and unlawful abuse of a dominant position pursuant to Article 102 TFEU. The Commission's theory is interesting for it seems based on the view that the very existence of payment is suggestive that the patent is invalid, and that the patentee knows it. Therefore, a private settlement concerning a patent that may be invalid is, in itself, a restriction of competition. Why, after all, would a rational patent holder pay a generic manufacturer to withhold an invalidity application if its patent was valid?

This rule of inference is a coarse proxy. Amongst other rationales, the owner of a valid patent may settle a case because he is averse to the uncertainty of litigation; or simply because he is averse to litigation costs (financial and other); or because he is mistakenly convinced by the applicant's invalidity claim; or because he can, through a negotiated agreement, regain a level of control of the process.

At any rate, that antitrust agencies are suspicious of patents is clear, not only are they ready to assume invalidity pursuant to fragile inferential reasoning but they are also willing to look at the legitimate use of patents are a potential abuse.

e. Phasing out of IP-Protective Case LaW. In the EU, the upper courts have traditionally sought to protect patent rights in their case-law. To that end, they have fabricated three judicial doctrines that purport to "exceptionalize" antitrust enforcement against IP holders. First, the EU Courts consider that the application of competition rules cannot question the "existence" of IPRs, but simply their "exercise". For what it is worth, this suggests that antitrust agencies cannot pass judgment on the validity of patent rights, on the adequacy of patent offices' assessments, of patentability requirements, etc.

Second, the EU judicature has long held that there can be no infringement of competition law as long as the patent holder stays within the "specific subject matter" or seek to maintain the "essential function" of his right. And in Centrafarm v Sterling Drug, the Court defined the essential function of patents as the "exclusive right to use an invention with a view to manufacturing industrial products and putting them into circulation for the first time, either directly or by the grant of licences to third parties, as well as the right to oppose infringements". ${ }^{34}$

34 CJEU C 15/74, Centrafarm BV and Adriaan De Peijper v Sterling Drug Inc., ECR [1974] 1147, § 9. 
Third, in the area of abuse of dominance, where an antitrust duty to license may permeate through the so-called "essential facilities doctrine" ("EFD"), 35 the Courts have been keen to restrict it to "exceptional circumstances". ${ }^{36}$ They have furthermore granted clarifications on the concept of "exceptional circumstances" which, though open ended - there can, and there should be no list of exceptional circumstances - must, ${ }^{37}$ as it goes for all exceptions, be interpreted strictly and narrowly.

Interestingly, those protective case-law principles do not appear in the most recent EU Commission's soft law instruments related to patent rights, as if protective judicial precedent was being phased out from the law. This is very clear in the Article 101 Guidelines on horizontal cooperation agreements that cover joint R\&D and standardization agreements or in the Guidelines on technology transfer agreements. Both instruments elide the protective case-law of the Court of justice. ${ }^{38}$ And this is remarkable because generally, Commission's soft law instruments are replete with case law citations.

ろ. The "Transactional licensing" Practice. To be sure, with four cases brought to completion in 50 years, the amount of compulsory licensing achieved on the basis of the EU competition rules has been statistically insignificant, if not trivial. ${ }^{39}$ But a more significant degree of antitrust licensing has taken place through other, less visible, mechanism. For instance, in the past 5 years, the EU Commission has settled 3 proceedings with dominant firms in exchange for a pledge to grant IPR licenses (in Rambus, S\&P and Thomson Reuters).

Moreover, in the area of merger control, IPR licensing is the single most important remedy applied as an alternative to a corporate carve out.40 For instance, in Shell/BASF (Project Nicole), the parties committed to openly license - and not to assert - patent rights over metallocene, a chemical

$35 \quad$ According to this doctrine, a dominant firm can be compelled to open access to its inputs, including intangible ones, to competitors, if this is necessary to remove a restriction of competition in a related, secondary market.

36 See CJEU, Case C-241/91 P and C-242/91 Radio Telefis Eireann (RTE) and Independent Television Publications Ltd (ITP) v Commission (Magill) [1995] 743 at §50; Case C-418/01 IMS Health, GmbH \& Co. OHG v NDC Health GmbH \& Co. KG [2004] I-5039 at $\S 35$ to 37. This precedent is also the one affirmed by the General Court in Microsoft III (the socalled 'compliance' case). Case T-167/08 Microsoft Corp. v Commission, (also known as the compliance case) not yet published at $\$ 335$.

37 Our reading of GC T-201/04, Microsoft v Commission, ECR [2004] II-3620, §332.

$38 \quad$ See http://eur-lex.europa.eu/LexUriServ/LexUriServ.do?uri=CELEX:52011XC0114(04):EN:HTML and http://ec.europa.eu/competition/consultations/2013_technology_transfer/guidelines_en.pdf

39 See cases referenced above.

40 See for instance, Commission Decision, Axalto/Gemplus, Case No COMP/M.3998 [2006] SG-Greffe (2006) D/202682; Intel/McAfee, Case No COMP/M.5984, C (2011) 529 final. See also D. Hoeg, European Merger Remedies, Law and Policy, Hart Publishing, 2013, pp.87-88. 
compound. ${ }^{41}$ In some transactions, the Commission has even nudged the merging parties to offer to sell IPRs in order to assist the emergence of a new industry player. ${ }^{42}$

Importantly, transactional antitrust licensing may even occur more informally. When Google sought to acquire the stockpile of patents detained by Motorola Mobility in 2011, the Commission observed that Google had issued a letter to Standard Setting Organisations ("SSOs") committing to FRAND licensing and good faith negotiations with licensees. But the Commission's concerns were only soothed when Google clarified the implications of this letter, and in particular that the letter had "binding legal effects" and was "irrevocable". 43

To sum up, beneath the tip of the compulsory licensing iceberg, looms a large amount of antitrust licensing activity.

П. The "Estoppel" Abuse Doctrine. A possible interpretation of the controversial ruling of the CJEU in Konkurrensverket $v$ TeliaSonera Sverige $A B$ is that once a dominant firm has voluntarily chosen to supply a customer, it can no longer refuse to deal, and this notwithstanding the fact that the restrictive conditions of an antitrust duty to supply may not be fulfilled. 44 This interpretation, which remains subject to discussion, ${ }^{45}$ is the one endorsed by certain officials of the EU Commission. Coates talks of an "Estoppel" abuse. In his view, this reading of the judgment is appropriate because customers make commercial decisions on the basis of the offer to supply, and it would be unfair to hold them up ex post with supply-disruption threats. ${ }^{46}$

In relation to IPRs, Konkurrensverket $v$ TeliaSonera Sverige AB suggests that a dominant patentee who grants a license may be "estopped" from the ability to revoke it freely. This is because licensees make early "make or buy" business choices on the basis of patent holders' licensing policies.

$\boldsymbol{\Sigma}$. THE "USE IT OR LOSE IT" DOCTRINE. In some policy circles, the view holds sway that antitrust agencies should impose compulsory licensing on patent owners who do not manufacture or license their IPRs.

41 See Commission Decision, Case No COMP/M.1751, Shell / Basf / JV Project Nicole. See, for another example, Commission Decision, Case No COMP/M.1835, Monsanto (USA)/Pharmacia \& Upjohn (USA).

42 See Commission Decision, Cisco/Tandberg, Case No COMP/M.4063, SG-Greffe (2006) D/200788.

43 See Commission Decision, Google/Motorola Mobility, Case No COMP/M.6381.

44 See CJEU, C-52/09 Konkurrensverket v TeliaSonera Sverige AB [2011] I-00527, §58.

$45 \quad$ In terms of its scope, notably: does the self-imposed duty apply to existing customers only, or to prospective customers too?

$46 \quad$ http://www.twentyfirstcenturycompetition.com/2013/10/the-estoppel-abuse/ 
Sharon Bowles, a Member of the European Parliament and Chair of its IMCO Committee, ${ }^{47}$ recently asserted at the European Commission's Competition Day:

"I also think that you could use compulsory licensing more. You should also remove injunctory rights if the patents are not being actually worked. The whole point of having an injunction to stop somebody from infringing is to protect your market, your investment. If you are not working the patent, i.e. not yourself manufacturing or you don't have the licensee, you shouldn't have the right to stop somebody else. [...] Indeed I would even go so far as to say that if you are not working it, there should be compulsory licensing. [...] Everybody argues that it is complicated to negotiate a license, but if the will was there it could be done. And I think the will - could be imposed though competition policy."

This "use it or lose if" doctrine has not (yet) been turned into administrative enforcement or judicial precedent. And it may never be given its far reaching encroachment upon century-old general principles of law, such as the law on trespass or the right to property protected by Article 17 of the Charter on the Fundamental Rights of the EU.48 But the fact that Mrs Bowles felt confident enough to moot this idea as a credible one, and at such a gathering, is notable.

The potential effects of the "use it or lose it" doctrine on patent holders remain uncertain, but taken to its ultimate conclusion it dictates to inventors how to run their business, whether or not they are able or in a position to commercialise their invention. In addition, when read in conjunction with the estoppel abuse doctrine of Konkurrensverket $v$ TeliaSonera Sverige $A B$, the "use it or lose it" doctrine risks yielding a "catch 22" situation for patent holders: if they license, they can no longer withdraw their license; And if they do not, they can be forced to license.

Ф. INNOVATION AS A "FREE LUNCH"? In the literature, scholars increasingly challenge the causal role of patents in incentivising innovation. Larouche and Schinkel cite to previous research to argue that "ideas are often scarce, and will not necessarily be generated by investment. Ideas are unpredictable; they can, and often do, arise outside of well-planned efforts to produce them". ${ }^{4}$

\footnotetext{
47 The IMCO Committee is the Internal Market and Consumer Protection committee of the European Parliament.

48 See Article 17 of the Charter of Fundamental Rights of the European Union, 7 December 2000, Official Journal of the European Communities, 18 December 2000 (OJ C 364/01) which states that: "1. Everyone has the right to own, use, dispose of and bequeath his or her lawfully acquired possessions. No one may be deprived of his or her possessions, except in the public interest and in the cases and under the conditions provided for by law, subject to fair compensation being paid in good time for their loss. The use of property may be regulated by law insofar as is necessary for the general interest. 2. Intellectual property shall be protected".
}

49 See Larouche, Pierre and Schinkel, Maarten Pieter, Continental Drift in the Treatment of Dominant Firms: Article 102 TFEU in Contrast to $\S 2$ Sherman Act (May 2013). TILEC Discussion Paper No. 2013-020. Available at SSRN: http://ssrn.com/abstract=2293141 or http://dx.doi.org/10.2139/ssrn.229314 
Besides, the popular perception that innovation can arise accidentally - think of penicillin, microwave ovens, NutraSweet and vulcanized rubber - 50 or benevolently - think of the Steve Jobs and Steve Wozniak "garage" story - has gained immense traction.

This lends credence to the view that policy efforts aimed at channelling, stimulating, organising or even controlling innovation are vain.

But, this seems too much anecdotal and fragile ground to throw the baby with the bathwater, and significantly undermine patent protection. Many studies highlight that innovation thrives within an environment with some structure and organisation. ${ }^{51}$ Patent law just provides this, just like technological clusters or tax incentives.

\section{A Tale of a "Black Swan"}

Despite the above, the actual award of compulsory licenses by domestic authorities pursuant to the FCL or by antitrust agencies on the basis of abuse of dominance rules should remain the exception rather than the rule (despite the inordinate amount of academic literature devoted to these issues). Antitrust enforcement is case focused. And even if international trade law was ever to request countries to "flexibilise" compulsory licensing on specified technologies, such provisions would only be exceptionally enforced. Therefore, it is tempting to dismiss concerns, for such compulsory licenses will remain rare. Nicholas Banasevic, a senior official of the EU Commission in charge of the global smartphone war said just this: "It's important to remember that antitrust intervention in IP is very rare" "Some of the cases [at the moment] are very high-profile, that's why they get more prominence. But [antitrust intervention] is over-stated". 52

But are rare events really devoid of effects on economic agents? In his best-selling book "The Black Swan: The Impact of the Highly Improbable" of 2007, Taleb shows that "rare" events - he calls them "black swans" - have profound consequences on day to day markets, which go beyond short term turbulences. A rare event is "an event that comes as a surprise, has a major effect, and is often inappropriately rationalized after the fact with the benefit of hindsight". ${ }^{3}$ Examples include the discovery of the black swan in Australia, World War I, the 2007 financial crisis, or the Fukushima meltdown. Taleb explains that following a rare event, economic agents exhibit a "retrospective

\footnotetext{
50 See http://www.innovationexcellence.com/blog/2012/09/09/innovation-is-no-accident/\#sthash.vRDj6QzV.dpufor benevolently. 51 See more at: http://www.innovationexcellence.com/blog/2012/09/09/innovation-is-noaccident/\#sthash.vRDj6QzV.dpuf

52 See Nicholas Banasevic, Global Competition Review, 8 October 2013.

53 See http://en.wikipedia.org/wiki/Black_swan_theory
} 
predictability" bias. Because of psychological quirks, economic agents tend to believe ex post that the event, despite its objective ex ante improbability, was just bound to happen. ${ }^{54}$ In turn, market players make excessive, unnecessary adjustments. Since the Fukushima meltdown, many countries insulated from risks of seism have nonetheless phased out civil nuclear power. Closer to the business community, since the 2007 crisis, traders on financial markets use mathematical risk models which overly anticipate bank defaults. Those models may have later contributed to "double dip" recession spirals.

What does the black swan metaphor suggest in relation to patent law? After all, compulsory licensing is nothing comparable, even by a close call, to a nuclear meltdown in terms of human, environmental, and political consequences. That said, for millions of innovative firms whose whole and sole horizon is the marketplace, a patent - or a patent portfolio - is the lynchpin of their business model.

With this in mind, our opinion is that the mere prospect of sporadic trade or antitrust licenses risks affecting patentees' incentives to create and disseminate. Van Overwalle and Van Zimmeren - who cannot be categorized as IP activists - already find that existing compulsory licensing provisions, even though rarely enforced, have "an indirect, preventive effect" (Van Overwalle and Van Zimmeren, 2011). They add that those "provisions are more than a paper tiger". ${ }^{55}$ In reality, such cases, though at the fringes, risk being used by antitrust agencies "pour encourager les autres"56 in order to corral markets.

In the real world, we may just be witnessing the early consequences of trade and antitrust black swans. For example, despite the absence of any case-law precedent holding that the seeking of an injunction for patent infringement can be abusive (unless it comes within the ambit of the "sham litigation" judicial doctrine), Samsung withdrew in December 2012 all of its European injunction requests before national courts, wary of a finding of abuse, with a hefty antitrust fine... ${ }^{57}$ Is this empirical proof that stealth licensing affects patent holders, and can lead natural and legal persons to forfeit their most fundamental right, that of access to court?. Similarly, in public statements, European companies keep expressing

\footnotetext{
54 Everyone in his life, including the author of this paper, has once said "I knew it" when confronted with an unexpected event.

55 See Van Overwalle and Van Zimmeren, "A Paper Tiger? Compulsory Licenses Regimes for Public Health in Europe" (December 1, 2010. International Review of Intellectual Property and Competition Law (IIC), January 2011, SSRN http://ssrn.com/abstract=1717974, p.37.

$56 \quad$ In his novel Candide Voltaire alluded to the execution of British Admiral Byng in 1756, shot for 'failing to do his utmost' in preventing the loss of Minorca. Candide comments that "In that country, it is wise to kill an admiral from time to time in order to encourage the others."

$57 \quad$ More fundamentally, many patent owners who anticipate plummeting licensing revenues, will recline on investing in R\&D, seek other channels of protection not subject to publicity requirements (trade secrets, for instance) or vertically integrate by acquiring prospective licensors. This is a deadweight loss. And the problem is that it is difficult to measure, for investment that does not take place cannot be calculated...
} 
grave concern about the level of regulatory activism and erosion of patent rights, to the point that their $\mathrm{R} \& \mathrm{D}$ and commercial strategies are changing to address the threat that this activism may lead to a change in the law.

\section{A Tale of a "Butterfly"}

\section{Presentation}

In a seminal 1972 article, Edward N. Lorenz a climate specialist, asked "Does the Flap of a Butterfly's Wings in Brazil Set Off a Tornado in Texas?". Or how, by virtue of global climatic interdependence, a negligible event in one region of the world can set off a cataclysm at the other end of the planet.

Lorenz's theory, also known as "chaos theory" has relevance for patent law. The symptoms of stealth licensing discussed under section III are often not enshrined in binding legal acts (such as infringement decisions with penalties and/or remedies), but rather come in the form of "soft law" instruments (such as Communications, Guidelines, Press Releases, Speeches, Reports, Discussion Papers, etc.). For instance, Joaquin Almunia, the EU Commissioner for competition has only rarely enforced the competition rules against patent owners. Yet, he has repeatedly sent words of warning to them. In a 2013 speech, he declared:

"Companies should spend their time innovating and competing on the merits of the products they offer - not misusing their intellectual property rights to hold up competitors to the detriment of innovation and consumer choice"58

This policy of using "soft law" instruments to address the potential harm to competition associated with patents cannot, in and of itself, be criticized.59 However, like the flap of a butterfly, patent-adverse statements are not innocuous. In the global antitrust community, a soft law declaration by agency $X$ may well be transformed into hard decisional initiatives by authority $Y .60$ Or, less directly, a soft law declaration by agency $X$ may well inspire a complainant in jurisdiction $Y$. Or, even less straightforwardly, a soft law declaration by agency $X$, may trigger decisional or regulatory intervention by non-antitrust organs in country $\mathrm{Y}$. Judge Posner has distinctly referred to this as the "cluster bomb" effect of antitrust interventions. ${ }^{61}$

58 See Commissioner Almunia, "Antitrust: Commission sends Statement of Objections to Motorola Mobility on potential misuse of mobile phone standard-essential patents”, European Commission, IP/13/406 06/05/2013.

59 After all, rather than addressing patent holders conduct through ex post punitive enforcement, it is probably a good thing that many agencies have preferred the humble approach of leaving the issue of infringement undecided, and to provide positive guidance ex ante.

$60 \quad$ See, on this, M-Lex, "US is model for developing countries on Antitrust, IP and should move cautiously, top patent judge says", 9 January 2004, Leah Nylen, alluding to public statements from US Judge Randall R. Rader.

61 See R. Posner, Antitrust Law, University of Chicago Press, Chicago, 2001, $2^{\text {nd }}$ edition. 
This twin dynamic of propagation and amplification should not be underestimated. There are approximately 128 antitrust agencies in the world, ${ }^{62}$ and they increasingly operate as networks. Moreover, every year, new agencies are created. Those new agencies have a natural desire to build a reputation on the international scene. They may thus have a bias for big, headline grabbing cases, such as patent cases. ${ }^{63}$

Moreover, this "butterfly effect" may have dramatic impact, if antitrust action in country $Y$ mistakenly interprets the content of the source on which it relies in country $X$. This concern is not merely academic. In a 2013 speech at George Washington University, Commissioner Ohlhausen from the Federal Trade Commission (FTC) expressed this fear directly. She observed:

"our actions, if not properly explained, may send a message to our foreign counterparts that we do not place a very high value on intellectual property rights, which is clearly inconsistent with the appreciation for IP rights that we typically hold in the United States. Let me share with you an example of what I mean. Recently, I was in China attending a conference and meeting with Chinese competition officials. At the conference, I heard people claim that the United States has a well-established essential facilities doctrine, which is not exactly correct. In addition, it was suggested that when read in light of this doctrine, the FTC's Google decision implies that a SEP [Standard Essential Patent] is an essential facility and an unreasonable refusal to license that SEP constitutes monopolization. It was further suggested that the best remedy for monopolization with a SEP would be compulsory licensing because permitting more parties to use the SEP would facilitate competition. This is not a correct reading of relevant U.S. law or, in my opinion, of the FTC's decision in Google". 64

\section{Empirical Verification}

On the facts, several antitrust cases support our "butterfly effect" theory. Importantly, those cases which mostly originate in the pharmaceutical industry, may serve as blueprints for enforcement in many other sectors of the economy. In the Sanofi-Aventis case of 2013, the French antitrust agency found that Sanofi-Aventis had actively pursued a strategy to discredit generic versions of Plavix® (one of the world's best-selling drugs) by seeking to convince doctors and pharmacists that there was no substitute for the drug, except for its own generic version. The French Authority considered this to be manifestly incorrect and that discrediting generic products therefore constituted a strategy to exclude competition. It meted out a $€ 40.6$ million fine on Sanofi-Aventis on grounds of unlawful abuse of dominance. Interestingly, discrediting or denigration of a rival product had to date never been deemed unlawful under Article 102 TFEU. The French agency however felt confident to expand the boundaries of Article

\footnotetext{
62 See http://www.internationalcompetitionnetwork.org/uploads/library/doc905.pdf

63 Not to talk of the developing world, where antitrust regimes may be used with protectionist purposes.

64 See http://www.ftc.gov/sites/default/files/documents/public_statements/recent-developments-intellectual-propertyand-antitrust-laws-united-states/130617intellectualpropertyantitrust.pdf
} 
102 TFEU, by reference to a largely controversial EU Commission report issued previously in the context of the Pharmaceutical sector inquiry. In this document, the Commission had surmised that disparagement may be deemed an abusive strategy. The French agency quoted the Commission's report as a basis for deciding that the conduct of Sanofi-Aventis was likely to inflict severe competition harm. ${ }^{65}$ This was regardless of the fact that neither the EU Courts, nor the Commission had ever applied Article 102 TFEU to disparagement.

The Pfizer Xalatan case of 2012 even more clearly brings empirical evidence of the butterfly effect of soft law pronouncements. Here, the Italian Competition Authority found that Pfizer had abused a dominant position by attempting to unduly prolong the patent protection of its drug Xalatan, through the filing of divisional patent applications and the request for a Supplementary Protection Certificate ("SPC") on this basis. ${ }^{66}$ This case broke new ground, because unlike previous cases where pharmaceutical firms had been sanctioned for misleading patent examiners, this decision sanctioned a legitimate, nonmischievous, patenting application strategy (Graf, 2012). ${ }^{67}$ Unsurprisingly, the decision - later remanded on first instance review, and then reinstated on appeal - shocked the IP community. ${ }^{68}$ But the Pfizer Xalatan case is an explicit offshoot of the EU pharmaceutical sector inquiry. Both the introductive and conclusive sections of its decision refer to the EU Commission report as the basis for finding that filing divisional patents and SPCs may constitute an abusive strategy. ${ }^{69}$

65 See Autorité de la concurrence, Décision n 13-D-11 du 14 mai 2013 relative à des pratiques mises en oeuvre dans le secteur pharmaceutique at $\$ 659$, foonote 267 , quoting the Executive Summary of the Pharmaceutical Sector Inquiry Report at p. 14: "Originator companies devote a significant part of their budgets to marketing of their products with medical doctors and other health care professionals. The sector inquiry produced indications that some originator companies sought to put into question the quality of generic medicines, as part of a marketing strategy, and even after the generic product was authorised by the relevant authorities and was available on the market".

66 In essence, the ICA considered that the filing of the divisional patent, which did not cover a different invention to the parent patent, constituted double patenting. It also took objection with the fact that it had not told the Italian Patent Office that the patent was a divisional patent. Finally, it was concerned that this was a way, in Italy, to obtain protection where it had failed to obtain it on the basis of the original patent. "Italy: The Competition Authority fines anti-competitive Practices aimed at delaying Market Entry for generic Medicine", ECN Brief, 01/2012, p. 3 . See http://ec.europa.eu/competition/ecn/brief/01_2012/it_medi.pdf.

67 See T. Graf, "Italian Competition Authority Challenges Patent Measures", Kluwer Competition Law Blog, 23 January 2012, available at: http://kluwercompetitionlawblog.com/2012/01/23/italian-competition-authority-challengespatent-measures/

68 See http://thespcblog.blogspot.co.uk/2014/02/italy-consiglio-di-stato-reinstates.html

$69 \quad$ See $\$ 25$ of the ICA Decision, for instance. Even more explicitly, the ICA states at §178: "Ai fini della valutazione della natura anticoncorrenziale dei comportamenti di Pfizer, si osserva, in primo luogo, che essi devono essere ricondotti nell'ambito delle strategie escludenti, individuate della Commissione europea nella recente indagine sulla concorrenza nel settore farmaceutico, poste in essere dalle società originator al fine di ritardare o impedire l'accesso a mercato delle specialità generiche. Tra le strategie difensive delle imprese innovatrici figura, infatti, la presentazione di numerose domande divisionali sullo stesso brevetto, volte a bloccare lo sviluppo di un nuovo farmaco concorrente attraverso la costituzione di una fitta ragnatela brevettuale a protezione di una medesima specialità medicinale". 
Besides those clear-cut cases, several compulsory licensing judgments and decisions may have been facilitated by the climate of suspicion caused by patent-adverse soft law statements in other regions of the world, including the headline grabbing Indian decision in Natco $v$ Bayer to grant a compulsory license over Nevaxar, an anti-cancer drug; ${ }^{70}$ or the 2009 decision of the Taiwanese Fair Trade Commission that Sony, Royal Philips corporation, and Tayio Yuden Co Ltd jointly maintained a monopolistic position in the CDR market by virtue of a patent pool, and had abused this market position by charging excessive, non-negotiable royalties, prohibiting challenges to their patents, and failing to disclose important trading information. ${ }^{71}$

\section{Conclusion}

A pervasive and subtle form of stealth licensing is taking place in the realm of economic regulation, through top down through calls for a "flexible" interpretation of the TRIPS agreement, and bottom up through the facilitation of antitrust intervention against patent holders.

This paper has submitted that this novel stealth licensing paradigm risk squeezing the two main social functions of patent law, that is to protect patent holders incentives to create and disseminate.

Concretely, such stealth threats on the patent system are likely to affect firms' return prospects, and in turn their business strategies (in terms of dissemination, investment choices, etc.). The mere prospect of sporadic trade or antitrust licenses suffices to change patentees' incentives to create and disseminate as has been documented in the patent literature (Van Overwalle and Van Zimmeren, 2011).

Moreover, compulsory licensing for a particular technology has a detrimental effect on technology transfer towards developing countries, as it decreases the incentive for other multinational companies to engage in joint ventures with local firms in that state (Fair, 2009).

Interestingly, the EU and its Member States have felt necessary to recently recall, in the context of a WIPO committee, the view that technology is developed in order to be deployed, and that the patent system is an enabler of technology transfer:

"Possible further activities of this [WIPO] committee in relation to the transfer of technology should be balanced, and objective, and considered in light of the great many examples of the

\footnotetext{
70 See S. Vinod, "Guest post: Eye witness account of India's first compulsory licensing appeal before the IPAB", http://spicyip.com/tag/natco-vs-bayer; Bayer Corporation v. Natco Pharma Ltd., Order No. 45/2013 (Intellectual Property Appellate Board, Chennai), available at http://www.ipab.tn.nic.in/045-2013.htm.

71 See Taiwan Fair Trade Commission Decision of October 28, 2009 (the 938th Commissioners' Meeting), Disposition Kung Chu Tzu No. 098156 For more, see http://apps.americanbar.org/antitrust/at-committees/ats2/ebulletins/2009/December2009.pdf
} 
benefits of the patent system to technology transfer, and the relatively fewer examples of the patent system as an impediment'. ${ }^{\prime 2}$

And they added:

"The mere existence of IPRs on a product is not a barrier to, nor its absence a guarantee of, access to that product". ${ }^{73}$

Words of wisdom...

72 See 20th Session of WIPO Standing Committee on the Law of Patents (Geneva, 27 - 31 January 2014) - Final EU statements, http://www.parlament.gv.at/PAKT/EU/XXV/EU/01/09/EU_10910/imfname_10436323.pdf, 10.

$73 \quad$ Idem. 


\section{Bibliography}

\section{Scholarship and Studies}

Anderman, S. and Ezrachi, A., Intellectual property and competition law: new frontiers, Oxford, New York, Oxford University Press, 2011, 495 p.

Arrow, K. J., The Economic Implications of Learning by Doing, The Review of Economic Studies, Volume 28, Issue 3, 1962, 155-173.

Barton, J. H., Intellectual Property and Access to Clean Energy Technologies in Developing Countries: An Analysis of Solar Photovoltaic, Biofuels and Wind Technologies, ICTSD Trade and Sustainable Energy Series Issue Paper No. 2, International Centre for Trade and Sustainable Development, Geneva, 2007, 50 p.

Bostyn S. and Petit N., Patent=Monopoly: A Legal Fiction, 2013, 19 p., available at: http://ssrn.com/abstract=2373471 or http://dx.doi.org/10.2139/ssrn.2373471.

Cheung, S., "Property Rights in Trade Secrets", 20 ECON. INQUIRY 40, 49 (1982).

Cheung, S. (1986), "Property rights and invention", Research in Law and Economics, 8, p. 5-18.

Copenhagen Economics, 2009, Are IPR a Barrier to Transfer of Climate Change Technology?, Report to Directorate General of Trade, European Commission, January 19

Czapracka, K. A., "Where Antitrust Ends and IP Begins - on the Roots of the Transatlantic Clashes", 9 YALE J.L. \& TECH., 2007, 66 p.

Fair R., "Does Climate Change justify Compulsory Licensing of Green Technology?", International Law and Management Review, Vol.6, Winter 2009, p. 21

Fine, F., European Community Compulsory Licensing Policy: Heresy Versus Common Sense, 24 NW. J. INT'L L. \& BUS, 619, 2004, 29 p.

Gallini, N. T. and R. A. Winter, Licensing in the theory of innovation, RAND Journal of Economics, 16, 1985, p. 237-52.

Gambardella, A., Giuri, P. and A. Luzzi (2007) "The Market for Patents in Europe", Research Policy 36 (8), 2007, p. 1163-1183. 
Graf, T., "Italian Competition Authority Challenges Patent Measures", Kluwer Competition Law Blog, 23 January 2012, available at: http://kluwercompetitionlawblog.com/2012/01/23/italian-competition-authority-challengespatent-measures/.

Gupta, R. R., Compulsory Licensing in TRIPS: Chinese and Indian Comparative Advantage in the Manufacture and Exportation of Green Technologies, Sustainable Development Law \& Policy 12, no. 3, 2012, 21, p. 54-55.

Heald, P. J., A Transaction Costs Theory of Patent Law, 66 OHIO ST. L. J. 473, 2005, p. 487-489.

Henry G., "Intellectual Property Rights and Green Technologies", 42 ${ }^{\text {nd }}$ World Congress of the International Association for the Protection of Intellectual Property, October 2010, mimeo.

Holgersson, M., Patent management in entrepreneurial SMEs: A literature review and an empirical study of innovation appropriation, patent propensity, and motives, R\&D Management, Vol. 43, Issue 1, 2013, p. 21-36.

Käseberg, T., Intellectual property, antitrust and cumulative innovation in the EU and the US, Oxford, Portland, Oregon, Hart Publishing, 2012, 301 p.

Kitch, Edmund W.,"The nature and function of the patent system", The Journal of Law and Economics (1977), No. 20, p. 265-90.

Lana, E. L., "Clean Tech Intellectual Property: Eco-marks, Green Patents, and Green Innovation", Oxford, Oxford University Press, 2011, 276 p.

Landes, W. M., Posner, R. A., The Economic Structure of Intellectual Property Law, Harvard University Press, 2003, $442 \mathrm{p}$.

Larouche, P. and Schinkel, M. P., Continental Drift in the Treatment of Dominant Firms: Article 102 TFEU in Contrast to $\S 2$ Sherman Act, TILEC Discussion Paper No. 2013-020, 2013, 34 p., available at SSRN: http://ssrn.com/abstract=2293141 or http://dx.doi.org/10.2139/ssrn.229314.

Lemley, M. A., The Myth of the Sole Inventor, to appear in MICHIGAN LAW REVIEW, 110, 2011, p. 1104, Available at http://ssrn.com/abstract $=1856610$.

Long, C., Patent Signals, Universiity of Chicago Law review, Vol. 69, No. 2, 2002.

McDonough, J. F., The Myth of the Patent Troll: An Alternative View of the Function of Patent Dealers in an Idea Economy, Emory Law Journal, Vol. 56, 2006 p. 189; Emory Public Law Research Paper No. 076; Emory Law and Economics Research Paper No. 07-7. Available at SSRN: http://ssrn.com/abstract=959945. 
Merges, Robert P., A Transactional View of Property Right, 2005, 50 p. Available at SSRN: http://ssrn.com/abstract=707202 or http://dx.doi.org/10.2139/ssrn.707202.

Perez Pugatch, M., "When Policy meets Evidence: What's next in the discussion of intellectual property, technology transffer and the environment", Global Challenges Brief, WIPO, 2011

Posner, R., Antitrust Law, University of Chicago Press, Chicago, 2001, $2^{\text {nd }}$ edition, $304 \mathrm{p}$.

Scherer, F.M., Industrial Market Structure and Economic Performance, Rand McNally Pub. Co, Chicago, 1980, $632 \mathrm{p}$.

Troy, I. and Werle, R., Uncertainty and the Market for Patents, Köln: Max-Planck-Institut für Gesellschaftsforschung, Working Paper 08/2, 2008, 26 p.

UNEP, EPO and ICTSD study, Patents and Clean Energy: Bridging the Gap between Evidence and Policy, $\quad 30 \quad$ September 2010, available at http://documents.epo.org/projects/babylon/eponet.nsf///cc5da4b168363477c12577ad00547289/\$FILE/patents_clean_energ y_study_en.pdf

Van Zimmeren, E. and Van Overwalle, G., "A Paper Tiger? Compulsory License Regimes for Public Health in Europe", International Review of Intellectual Property and Competition Law (IIC), 2011, p. 440.

Vinod, S., Guest post: Eye witness account of India's first compulsory licensing appeal before the IPAB, http://spicyip.com/tag/natco-vs-bayer; Bayer Corporation v. Natco Pharma Ltd., Order No. 45/2013 (Intellectual Property Appellate Board, Chennai), available at http://www.ipab.tn.nic.in/045-2013.htm.

Wu, T., Columbia University, Oversight of Innovation Catalysts, 2012 OECD Competition Committee Hearings on the Digital Economy.

\section{Legislation}

Agreement on Trade-Related Aspects of Intellectual Property Rights, April 15, 1994, Marrakesh Agreement Establishing the World Trade Organization, Annex 1C, 1869 U.N.T.S. 299, 33 I.L.M. 1197 (1994).

Declaration on the TRIPS Agreement and Public Health, WT/MIN(01)/Dec/2, 14 November 2001, available at http://www.wto.org.

Charter of Fundamental Rights of the European Union, 7 December 2000, Official Journal of the European Communities, 18 December 2000 (OJ C 364/01). 
European Parliament, Resolution of 29 November 2007 on trade and climate change (2007/2003(INI)) Green position paper (2012) Climate change, Technology Transfer and Intellectual Property: http://www.greens-efa.eu/climate-change-technology-transfer-and-intellectual-property-5484.html.

\section{Official Speeches, Press and Working documents}

Commissioner Almunia, "Antitrust: Commission sends Statement of Objections to Motorola Mobility on potential misuse of mobile phone standard-essential patents", European Commission, IP/13/406 06/05/2013.

EU Digital Agenda Action 25 at http://ec.europa.eu/digital-agenda/en/pillar-i-i-interoperability-standards/action-25identify-and-assess-means-requesting-significant and the European Commission's Staff Working Document http://ec.europa.eu/digital-agenda/en/news/analysis-measures-could-lead-significant-market-players-ict-sector-licenseinteroperability.

Almunia, J., Speech at Industrial policy and Competition policy: Quo vadis Europa?, New Frontiers of Antitrust 2012 - Revue Concurrences Paris, 10 February 2012.

M-Lex, EC to reveal position in tech-patents cases in 'near future,' Madero says, 7 December 12, Matthew Newman.

FCCC/AWGLCA/2009/8 19 May 2009, Ad Hoc Working Group on Long-Term Cooperative Action under the Convention, Sixth session, Bonn, 1-12 June 2009.

Nicholas Banasevic, Global Competition Review, 8 October 2013.

20th Session of WIPO Standing Committee on the Law of Patents (Geneva, 27 - 31 January 2014) Final EU statements, http://www.parlament.gv.at/PAKT/EU/XXV/EU/01/09/EU_10910/imfname_10436323.pdf, 10.

WIPO, CDIP/4/4 Rev./STU*DY/INF/5, p. 24. 


\section{Internet Sources}

http://www.ip-watch.org/2009/04/01/cooling-the-world-by-misappropriating-patent-rights/

http://online.wsj.com/news/articles/SB124760260278140953

http://www.twnside.org.sg/title2/climate/info.service/2013/climate131011.htm

http://www.thehindubusinessline.com/industry-and-economy/us-eu-irked-by-indias-compulsory-licenceplan-for-green-technologies/article5193594.ece.

http://www.financialexpress.com/news/us-uk-question-nmp-s-green-tech-protection/1177391/1.

http://dev.theglobalipcenter.com/wp-content/uploads/GIPC_-_Green_Jobs_Leave_Behind.pdf.

http://unfccc.int/bodies/awg/items/6656.php\#workstreamone

http://eur-lex.europa.eu/LexUriServ/LexUriServ.do?uri=CELEX:52011XC0114(04):EN:HTML and http://ec.europa.eu/competition/consultations/2013_technology_transfer/guidelines_en.pdf

http://www.twentyfirstcenturycompetition.com/2013/10/the-estoppel-abuse/

http://www.innovationexcellence.com/blog/2012/09/09/innovation-is-noaccident/\#sthash.vRDj6QzV.dpufor benevolently.

http://www.innovationexcellence.com/blog/2012/09/09/innovation-is-noaccident/\#sthash.vRDj6QzV.dpuf

http://en.wikipedia.org/wiki/Black_swan_theory

http://www.internationalcompetitionnetwork.org/uploads/library/doc905.pdf

http://www.ftc.gov/sites/default/files/documents/public_statements/recent-developments-intellectualproperty-and-antitrust-laws-united-states/130617intellectualpropertyantitrust.pdf

http://thespcblog.blogspot.co.uk/2014/02/italy-consiglio-di-stato-reinstates.html 